\title{
Dealing with Project Based Learning during COVID-19: Teacher's Perception Using Educational Video as ELT Media
}

\author{
Putu Kerti Nitiasih \\ Universitas Pendidikan Ganesha \\ kertinitiasih@undiksha.ac.id \\ Luh Gd Rahayu Budiarta \\ Universitas Pendidikan Ganesha \\ rahayu.budiarta@undiksha.ac.id \\ Ni Luh Putu Era Adnyayanti \\ Universitas Pendidikan Ganesha \\ era.adnyayanti@undiksha.ac.id \\ Ni Nyoman Erinaryani \\ Universitas Pendidikan Ganesha \\ ninyomanerinaryani10@undiksha.ac.id
}

\begin{abstract}
This study aimed to determine teachers' perception toward teaching media in English language learning in the form of educational video using Project-Based Learning elementary school students. This research used case studies as the research method by using qualitative as the research design. Elementary school teachers in Buleleng regency were the object of this research. The content of the video was designed by using Project-based learning as the steps in delivering the material. The data were collected from interviews and a checklist. The analysis result of the research was most teachers preferred to use video as the learning media. The use of the video perceived positive perception by the teacher since video brings effective learning during the pandemic.
\end{abstract}

Keywords: educational video, teachers' perception, project-based learning

\section{INTRODUCTION}

COVID-19 is a new disease that caused a global pandemic these days. This deadly virus quickly infects human, mostly around the world. In Indonesia, this disease is started to appear at the beginning of March. Over than 40.000 Indonesian people infected by this virus. The pandemic affects almost all of social life worldwide, especially the education sector.

In order to avoid widespread virus distribution, a social distancing rule is established to avoid the surplus patients infected by COVID19. Many schools and colleges were forced to close temporarily due to the Covid-19 pandemic outbreak (Dhawan, 2020). Based on Surat Surat Edaran Nomor 15 Tahun 2020 tentang Pedoman Penyelenggaran Belajar Dari Rumah Dalam Masa
Darurat Penyebaran Corona Virus Disease (COVID-19) (2020), all the learning activities are conducted from home. This school from home conducted in the form of e-learning or online learning. During the pandemic, online learning means that teachers and students do not go to classes but instead teach and study from home using technology (Rahayu \& Wirza, 2020). This method is used in the school as a way to avoid COVID-19 transmission among the students, teacher, and all school's staff.

Contemporary advancements in digital technologies and knowledge have significance for school learning styles. E-learning, online learning, game-based learning, digital multimedia, computer-based learning, and other digital-based learning technologies enable students to study 
independently. Moreover, those give flexibility in time and space. The use of technology to conduct online learning during pandemic areas shows the educational impact of the industrial revolution in the 21st century or industrial revolution 4.0. Industrial revolution defined as the changes of industrial manufacturing towards some fields that has relation with industrial and technology (Schwab, 2017). Therefore, all educational institutions take advantages of this industrial revolution 4.0 to overcome educational issues during the COVID-19 pandemic.

The issues that usually found in online learning, especially in English teaching, are the capability of the teachers in transferring the material. Lestiyanawati \& Widyantoro, (2020) found that some e-learning challenges include a lack of technological expertise, infrastructure and services, teachers' teaching strategies, and economic issues. Some teachers still found some difficulties using appropriate media and keeping being communicative even though the learning activity conducted in the online form. Almosa (2002) stated that students and teachers have less interaction than they used to in conventional learning. In implementing this new learning style, teachers commonly use various strategies to use online learning to support the teaching and learning activity, especially in English Language Teaching (ELT). English is an international language that students need to be able to use the language as communication media. (Mahadewi, P., W., Sudirman, \& Wedhanti, N., 2018). Indonesia's students categorized as EFL learners, which commonly found some difficulties in mastering the basic English skill; listening, speaking, reading, and writing, due to the different structure and pattern with the native language (Budiarta, Suputra, \& Widiasmara, 2018). Thus, the teachers need to overcome the problems by using teaching media that is easy to use and give conventional experience even in online learning.

According to Omwenga, E. et al. (2004), elearning is learning media that could help the teachers provide and deliver the learning material through an internet access or online access, which could renew and develop the traditional learning media in the school or college. In delivering the learning material through online access, teachers need to have other media which make the classroom still interactive. One of the teaching media that support the e-learning process is an educational video. It will become an innovative way of teaching for teachers who conduct online learning. The educational video itself could make the learning activity becomes meaningful and interesting. According to Bajrami, L., \& Ismaili (2016), video learning could help the instructors give the students some visual aids related to learning material, making the students do not miss anything while studying by online learning. They also argued that video learning could make students more focused on practising their language skills, especially listening and speaking.

However, in making educational video, the teachers still need to set learning goals for the video learning itself. The goals must be considered the terms of 21st-century learning: communication, collaboration, critical thinking, and creativity (4Cs) (Libhi; et al., 2020)Therefore, the teacher needs to choose the right model to achieve those $4 \mathrm{Cs}$. One learning model that can be used is Project-Based Learning. Implementing project-based learning is proved to be an effective way to activate students' learning ability (A. \& Budiarta, 2019). Besides that, project Based Learning (PjBL) is a learning model that makes students not only memorize and understand the material but also demonstrate by applying certain material which related to the reallife task (learning by doing) (Virtue \& HinnantCrawford, 2019). The combination of educational video and Project-Based Learning reflects 21stcentury learning and industrial revolution 4.0 during the pandemic area. (Kimsesiz et al. (2017) researched implementing project-based learning to measure its effectiveness in teaching English vocabulary for young learners. Project-based learning led students to know many English vocabulary by the instruction or stages of projectbased learning. This learning approach was found to quite match with young learners' characteristics. Since young learners have a great curiosity, love to 
explore, and easy to get bored. Project-based learning let the students explore the subject matter by doing a project or making a product. Thus, they will enjoy the whole learning process.

In investigating the importance of the use of video as teaching media, Bajrami, L., \& Ismaili (2016) investigated the advantages of video material in their study about the role of video material in EFL Classrooms. The study aims to find out the advantages of video material in language learning of EFL students. The result of the study is that video material provides many advantages in language learning. Besides help teacher to stimulate students' interest and motivation in the learning process, video material could increase students' language skill because video provides images, audio, video, and text that could imitate by the students. Another study was conducted by Erizar et al. (2018), which found out the effectiveness of the implementation of multimedia for teaching English. The researchers found out that multimedia help the teacher to present the material effectively, and the students could understand the material easily. Therefore, it can be examined that the result of the study shows that the use of multimedia in English teaching has a significant effect on both teacher and students to get better experience in teaching and learning activities.

The teacher's role is essential to the effectiveness of implementing digital technology in elementary schools. Since it will bring multiple advantages, the teacher must use it efficiently in the classroom. However, in several regions, teachers face a significant obstacle in adapting to new technologies (Kurt, 2010). Other causes that became great obstacles in teachers' readiness to use digital media as a means of learning experience were investigated in this research. This research aims to enhance the development of digital technology in the twenty-first century by using Project-Based Learning.

\section{METHODOLOGY}

This study's methodology used a qualitative research design, specifically a case study. A case study aims to allow researchers to collect and analyze data in a particular context or phenomenon. During the COVID-19 Pandemic in Indonesia, the effect of video using project-based learning as an impact of school from home on elementary classroom teachers was investigated in depth in this study. The data were taken at elementary schools in Buleleng regency. It was collected at elementary schools in the Buleleng regency. The study's participants were elementary school English teachers. The following instruments were used to collect data: an interview guide, video learning, and an observation checklist. The interview guide provided direction for the interviewer in interviewing with the teacher to discover the issues experienced by the teacher during online learning. Video learning was used as the teaching media that the teacher used in the online classroom. The observation checklist was also used to describe teachers' perceptions toward using project-based learning in the video as English teaching media.

The following methods were used to conduct the research. The first step was data collection. The researcher gathered data relevant to the study using the data collection step and instruments used, such as video and syllabus. Second, through data reduction, the collected data were chosen, focused, and simplified based on the study's purpose. The researcher then began the process of organizing and categorizing the data.

The researcher presented the data in the form of a table and description based on the research instrument and data collection about teachers' perception of using project-based learning in video learning for sixth-grade elementary school students. The last part was the conclusion that was based on the result of data analysis.

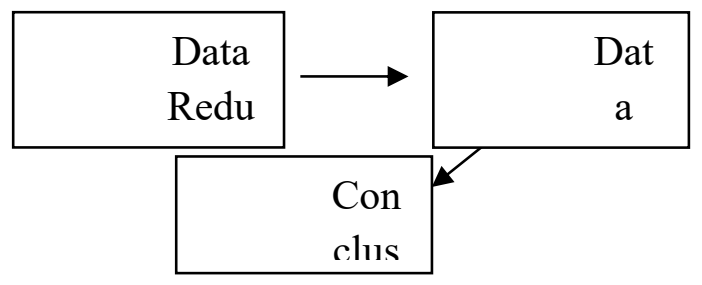

Figure 1. Figure of Data Analysis.

\section{RESULT AND DISCUSSION}


The results are classified into three types: (1) results from the interview guide to determine the kinds of media used by English teachers, (2) results from the checklist to determine students' attitudes to media usage, and (3) results from the questionnaire to determine teachers' perceptions of

\section{TEACHING MEDIA}

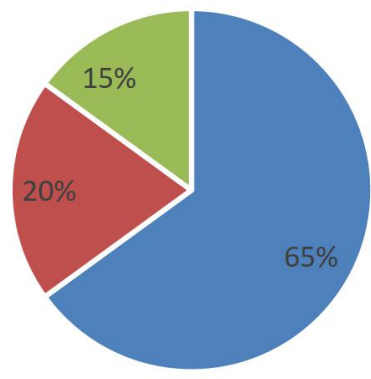

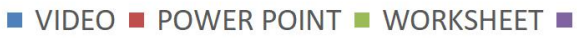

media use in the classroom.

Figure 2. Teaching Media Used by English teacher.

The interview guide was contained several questions related to the experience of both teacher and students in using teaching media in the online classroom. Moreover, the interview guide also led the researcher to determine teachers' teaching styles in English teaching.

The interview guide was about the kind of teaching media that had used by the teachers. Teaching media could attract students' attention, avoid boredom, and make the students easier to absorb the information (Mahadewi, P., W. et al., 2018). The teachers said that they used various teaching media during school from home. Mostly they used video and followed by using PowerPoint and worksheet for teaching English. English language teachers use various audio-visual resources to promote the teaching process, ensuring student-centric freedom, collaboration, and access to a specific theme. Videos such as instructional video, movies, songs, and PowerPoint presentations are commonly used in EFL classrooms (Dewanti, Batan, \& Suprianti, 2017). From the result above, it can be assumed that English teacher in Buleleng regency tends to use video as teaching media..

The checklist was to find out students' responses toward the implementation of video learning using project-based learning in English learning as the media. The students gave a positive response to the video. They enjoyed the video due to the various pictures, images, audio that support delivering the material. Buchner (2018) stated that to develop instructional video, the developer needs to integrate illustration with spoken text, highlight details, keep it clear, brief, and to the point, provide structure, and show and display a story.

Moreover, the benefits are the ability for students to pause, rewind, and control the study timeline. Furthermore, unlike the conventional classroom approach, learners who use an educational video may not miss their teacher's explanation since they have time to watch and recheck the videos whenever they need it (Beheshti, Taspolat, Kaya, \& Sapanca, 2018).

The teachers' perceptions were identified into three terms: perceptions of the effectiveness, how easy the video can be used, and attitude toward video learning. The degree to which an individual believes that using a particular system will improve their job performance is described as perceived usefulness or effectiveness (Rahayu \& Wirza, 2020). The teachers' perceptions data were collected through a checklist given. The results showed that the use of video using project-based learning improved teachers' performance in English teaching. For the teachers, it can be their source as the learning material. One of the advantages of making instructional videos for teachers is reusing videos for those other courses and semesters (Brame, 2015). The teacher would have sufficient time to prepare the learning activity because the media can be used repeatedly.

In terms of teachers' perceptions of how easy to use the video, the teachers perceived that the video was easily used and accessed. (Davis, Bagozzi, \& Warshaw, 1989) stated that flexibility is how an individual assumes that using a specific device would be quick and easy. The teachers only 
need to access the video through the Google Drive link and send it to the WhatsApp Group. The teachers do not need any other things to prepare the teaching media. The video using project-based learning already contain material explanation, examples, and exercises. The use of project-based learning could also build students interaction. The students are asked to do a project that needs some interactions with the teacher and the people around them. It supported by the theory from Astawa et al. (2018), which stated project-based learning lead the students to work on a project, by planning, implementing, reflecting, and evaluating the project as the way they acquire the knowledge.

From those perceptions of the usefulness and ease to use, it showed that the teachers have a positive attitude toward using project-based learning in the form of video learning. This media could attract students' attention and motivation to learn English during the pandemic. It is relevant to Jannah et al. (2020) which stated that using video as learning media gave some positive impacts, such as interactive learning activity, excitement during the learning activity due to audio and visual given in the video. Students could work in group and individually, and made students more focused also motivated in the learning process since something is interesting in the video. Interestingly, during the pandemic, the teachers showed a positive attitude toward using video using project-based learning in online teaching. Teachers' ability to use the video in online teaching and participation in it is very strong. They also believed that they should improve their digital multimedia capabilities as English language teaching media during the pandemic. This revealed that teachers understood the value of the video as the teaching media in their classroom activities.

\section{CONCLUSION}

In terms of the types of media used by English teachers, the interview results revealed that video is the most commonly used media by English elementary school teachers in Buleleng Regency. According to the checklist about students' responses to the video used, the students positively respond to the media. They feel that using video in class makes learning materials easier to understand. In terms of teachers' perceptions of the use of video in the classroom, the checklist results revealed that English elementary school teachers in Buleleng regency had a positive perception of the use of video in teaching English to students. They mostly claim that using video could allow teachers to perform higher performance and get various educational sources. The significance of using video for education is that it can be used to assist students in their studies and enable the teaching and learning process more effective and efficient. The use of video in association with project-based learning makes the content more engaging and clearer for students to understand. There are several benefits of using video in combination with project-based learning in the teaching-learning process. These are: learner motivation, preventing learners from being bored, making instructional content easier for students to understand and making the instructional learning process more comprehensive.

\section{REFERENCES}

A., N. L. P. N. S. P., \& Budiarta, L. G. R. (2019). MODEL PEMBELAJARAN BERBASIS PROYEK : PENGARUHNYA. Media Edukasi, $3(1), 71-77$.

Almosa, A. (2002). Use of Computer in Education, (2nd ed). Riyadh: Future Education Library.

Astawa, N. L. P. N. S. P., Artini, L. P., \& Nitiasih, P. K. (2018). Do Learners Like Project in Their English Classes ?: Impact of PBL on Students ' Attitudes. In SHS Web of Conferences (Vol. 00084, pp. 1-9). https://doi.org/https://doi.org/10.1051/shsconf /20184200084

Bajrami, L., \& Ismaili, M. (2016). The Role of Video Materials in EFL Classrooms. Procedia Social and Behavioral Sciences. Procedia Social and Behavioral Sciences, 232.

Beheshti, M., Taspolat, A., Kaya, O. S., \& Sapanca, H. F. (2018). Characteristics of Instructional Videos. World Journal on Educational Technology: Current Issues, 10(2), 79-87. https://doi.org/10.18844/wjet.v10i2.3418 
Brame, C. J. (2015). Effective Educational Videos. Vanderbuilt University Center for Teaching, 1-8.

Buchner, J. (2018). How to create Educational Videos: From watching passively to learning actively. REE Source, (12), 1-10.

Budiarta, L. G. R., Suputra, P. E. D., \& Widiasmara, I. K. (2018). an Analysis of Grammatical Errors on Narrative Writing Committed By the Ninth Grade Students of Junior High School. International Journal of Language and Literature, 2(3), 98-107. https://doi.org/10.23887/ijll.v2i3.16315

Davis, F. D., Bagozzi, R. P., \& Warshaw, P. R. (1989). User Acceptance of Computer Technology: A Comparison of Two Theoretical Models. Management Science, 35(8), 982-1003.

https://doi.org/https://doi.org/10.1287/mnsc.3 5.8.982

Dewanti, A. R., Batan, G., \& Suprianti, G. A. P. (2017). Teachers' Perception and Students' Responses Toward the Use of English Teaching Media in SD Laboratorium Undiksha Singaraja. Jurnal Pendidikan Bahasa Inggris, 5(2).

Dhawan, S. (2020). Online Learning : A Panacea in the Time of COVID-19 Crisis. Journal of Educational Technology, 49(1), 5-22. https://doi.org/10.1177/0047239520934018

Erizar, Syahputra, A., \& Hidayati, T. (2018). The Effectiveness of Use Multmedia in English Teaching at SMPN 1 Meulaboh. Advances in Social Science, Education and Humanities Research, (208), 47-48.

Jannah, M., Prasojo, L. D., \& Jerusalem, M. A. (2020). Elementary School Teachers' Perceptions of Digital Technology Based Learning in the 21st Century: Promoting Digital Technology as the Proponent Learning Tools. Al Ibtida: Jurnal Pendidikan Guru MI, 7(1), 1-18. https://doi.org/10.24235/al.ibtida.snj.v7i1.6088

Kementerian Pendidikan dan Kebudayaan. Surat Edaran Nomor 15 Tahun 2020 tentang Pedoman Penyelenggaran Belajar Dari Rumah Dalam Masa Darurat Penyebaran
Corona Virus Disease (COVID-19) (2020).

KIMSSESIZ, F., DOLGUNSÖZ, E., \& KONCA, M. Y. (2017). The Effect of Project Based Learning in Teaching EFL Vocabulary to Young Learners of English: The Case of Pre-school Children. International Journal of Languages' Education and Teaching, 5(4), 426-439.

Kurt, S. (2010). Technology Use in Elementary Education in Turkey: A Case Study. New Horizons in Education, 583(1), 65-76.

Lestiyanawati, R., \& Widyantoro, A. (2020). Strategies and Problems Faced by Indonesian Teachers in Conducting E- Learning System During COVID-19 Outbreak. CLLiENT Journal (Journal of Culture, Literature, Linguistics and English Teaching), 2(1), 71-82.

Libhi;, K. S. S., Nitiasih, P. K., \& Budiarta, L. G. R. (2020). INVESTIGATING THE EFFECT OF GAMIFIED BALINESE LOCAL STORIES AS A TEACHING MEDIA ON YOUNG LEARNERS'. JINOTEP (Jurnal Inovasi Teknologi Pembelajaran), 7(1), 1-8. https://doi.org/10.17977/um031v7i12020p001

Mahadewi, P., W., E., Sudirman, \& Wedhanti, N., K. (2018). THE PROFILE OF TEACHERS' TECHNIQUES, MEDIA AND MATERIAL OF TEACHING ENGLISH VOCABULARY TO YOUNG LEARNERS APPLIED AT AURA SUKMA INSANI KINDERGARTEN (A CASE STUDY). Jurnal Pendidikan Bahasa Inggris, 6(2), 21-28.

Omwenga, E., Mwololo, T., \& Wagacha, P. (2004). A Model for Introducing and Implementing e-learning for Delivery of Educational Content within The African Context. African Journal of Sciences and Technology, 5, 35-48.

Rahayu, R. P., \& Wirza, Y. (2020). Teachers ' Perception of Online Learning during Pandemic Covid -19. Jurnal Penelitian Pendidikan, 20(3), 392-406.

Schwab, K. (2017). The Fourth Industrial Revolution.

Virtue, E. E., \& Hinnant-Crawford, B. N. (2019). "We're doing things that are meaningful": Student Perspectives of Project-based Learning Across the Disciplines. 
Interdisciplinary Journal of Problem-Based

Learning, 13(2). 